Fig. 10. Melania subplicatula, p. 729.

11. Bullia persica, p. 730 .

12. Ostrea, attached to a Trochus, whose character of sculpture it has assumed, p. 730 .

13, 14. Cyprea peasei, var. monstrosa, p. 731.

16. Descriptions of some apparently new Species of Butterflies from New Ireland and New Britain, sent by the Rev. G. Brown. By F. D. Godman and O. Salvin.

[Received June 18, 1878.]

The five species described below form part of a collection just received from Mr. G. Brown. We are preparing a full report of this collection, which we hope to lay before the Society in the autumn. In the mean time we have thought it desirable to publish the following descriptions.

\title{
Euplea erimas.
}

o. Exp. 3.7. Upper surface rich steel-blue, a large patch of bluish white on the primaries cut by the dark median nervure and its branches and by the nervules at the end of the cell; there is a dark triangular spot in the acute angle between the median nervule and its first branch; the inner margin of the primaries is strongly convex, and covers a brown patch on the secondaries; the secondaries have a whitish median band cut by the nervules, one section falling inside the cell; the inner edge of this band is deeply sinuated, as also is the outer edge to a less extent.

Beneath greenish black, the spots of the upper surface are much more broken up, that on the primaries being divided into eight separate portions, the largest of which lies just within the cell ; that on the secondaries is broken into eleven portions, one of which occupies the end of the cell.

Hab. New Ireland.

Obs. Allied to $\boldsymbol{E}$. jessica from the Fiji Islands, and more remotely to $E$. eupator, Hew., from Celebes. From the former it differs in having the markings on the upper surface bluish white instead of yellow, and the spot on the upper wing is not broken into two as shown in Mr. Butler's figure (Lep. Ex. pl. 8. fig. 3).

\section{Pieris madetes.}

J. Exp. 3.5. Above uniform orange, apex and costa of primaries black.

Primaries beneath black, a large spot at the end of the cell and seven large elongated submarginal spots yellow; a pale yellowish patch spreads from the inner margin over the median branches to just within the cell; secondaries orange, base and outer margin black, the latter including a row of six large yellow spots; a large red spot between the costal and subcostal nervures near their origin.

․ Exp. 3:8. Above, primaries black; a large yellowish spot at 
the end of the cell and six submarginal spots running from the costa to the anal angle, those nearest the latter nearly white; the central portion and inner margin of secondaries dull yellowish white, the base and outer margin broadly black, the latter including six obsolete yellowish spots.

Beneath like the male, except that the primaries have no yellowish spot spreading from the inner margin over the median branches.

$H a b$. New Ireland.

Obs. Belongs to the Delias group. The male resembles on the upperside the same sex of $P$. aruna, Boisd., as figured by Hewitson, and $D$. inferna, Butl. The female on the upperside, and both sexes on the under, more nearly resemble $\boldsymbol{P}$. descombresi, Boisd.

\section{Pieris eurygania.}

o . Exp. $3 \cdot 2$. Above white, the apex of the primaries chromeyellow, margined with the black costa and outer margin and a curved band running from inside the cell to near the anal angle, the outer margin of the secondaries broadly black.

Beneath, primaries chiefly black, yellow apical spot as on the upperside, the proximal end of the cell yellow, and the inner margin white; the secondaries at the basal half yellow, black towards the distal half, across the black a distinct band of crimson, which becomes orange where it meets the yellow near the inner margin.

ㅇ. Like the $\delta$, except that the basal portion of the primaries is black, the outer margin of the secondaries is more broadly black, and the inner portion of the secondaries, together with inner margin of the primaries, pale yellow.

Beneath same as the male.

$H a b$. New Ireland.

Obs. This is a very distinct species, apparently belonging to the Delias group.

\section{Pieris lytak.}

․ Exp. 2.5. Above black, a large subtriangular spot on the inner margin, extending to just within the cell, three apical spots of the primaries and the basal half of the secondaries white.

Beneath, black arranged as above, a submarginal row of large white spots on both wings ; the base of the primaries and the greater portion of the base of the secondaries sulphur-yellow; the rest of the secondaries (not occupied with black) is white.

Hab. New Britain.

A female, apparently belonging to the Belenois group; we have no nearly allied species with which to compare it.

\section{Papilio segonax.}

đ. Exp. 4.6. Primaries slightly falcate, secondaries produced, Upper surface rich metallic green, a median row of five nearly circular spots starting from the apex to the space between the third and fourth median nervules, a similarly coloured subtriangular spot near the middle of the inner margin, and a very small one close 
inside the submedian nervure. The proximal half of the secondaries greyish white, rather darker towards the anal angle.

Beneath umber-brown, the outer portion of both wings rather darker, the spots on the primaries as above.

$H a b$. New Ireland.

Obs. Allied to $P$. codrus, from which it differs in having the band of spots of the primaries interrupted, there being no spots in the spaces between the first and second, and second and third median branches, that between the first median branch and the submedian nervure being wanting. On the other hand, there is a spot on the inner margin of the primaries not usually seen in $P$. codrus. The single specimen sent by $\mathrm{Mr}$. Brown has the secondary wings slightly injured, so that the prolongation of the second median branch, common to all the allied species of the P.-codrus group, is broken off.

17. Reports on the Collections of Birds made during the Voyage of H.M.S. 'Challenger.'-No. XII. The Procellariidæ. By Osbert Salvin, M.A., F.R.S., \&c.

[Received June 18, 1878.]

Eighty specimens of Procellariidæ are comprised in the 'Challenger' collection, belonging to 22 species and 13 genera. The greater part of these were obtained during the visit to Kerguelen Island; others were secured at sea in the South Pacific Ocean, a few near the Straits of Magellan, at Nightingale Island, and elsewhere. None of the species present any difficulty as regards their nomenclature ; but I take this opportunity of adding a few notes on this subject gathered during recent study of the species to which they belong.

Oceanites oceanicus.

Procellaria oceanica, Kuhl, Beitr. p. 136, pl, x. f. 1.

Oceanites oceanica, Coues, Pr. Ac. Phil. 1864, p. 82 ; Salv. Orn. Misc. ii. p. 227.

$a-c$. Males.

d, e. Females. $\}$ Ice Barrier.

"Obtained on the 14th February, 1874."

Fregetta grallaria.

Procellaria grallaria. Vieill. N. Dict. d'Hist. N. xxv. p. 418.

Fregetta grallaria, Bp. Consp. ii. p. 197 ; Coues, Pr. Ac. Phil. 1864, p. 86.

Thalassidroma leucogastra, Gould, Ann. \& Mag. N. H. xiii. p. 367 , et B. Austr. vii. pl. 63 .

$\left.\begin{array}{l}\text { 568-571. Females. } \\ \text { 572, 573. Males. }\end{array}\right\}$ South Pacific.

"Eyes brown. Shot on the 11th November, 1875, at sea. Their 


\section{$2 \mathrm{BHL}$ Biodiversity Heritage Library}

Godman, Frederick Du Cane and Salvin, Osbert. 1878. "Descriptions of some apparently new Species of Butterflies from New Ireland and New Britain, sent by the Kev. G. Brown." Proceedings of the Zoological Society of London 1878, 733-735. https://doi.org/10.1111/j.1469-7998.1878.tb08016.x.

View This Item Online: https://www.biodiversitylibrary.org/item/90451

DOI: https://doi.org/10.1111/j.1469-7998.1878.tb08016.x

Permalink: https://www.biodiversitylibrary.org/partpdf/73530

\section{Holding Institution}

Natural History Museum Library, London

\section{Sponsored by}

Natural History Museum Library, London

\section{Copyright \& Reuse}

Copyright Status: Public domain. The BHL considers that this work is no longer under copyright protection.

This document was created from content at the Biodiversity Heritage Library, the world's largest open access digital library for biodiversity literature and archives. Visit BHL at https://www.biodiversitylibrary.org. 